\title{
Adducted thumbs-arthrogryposis syndrome, Christian type
}

INSERM

\section{Source}

INSERM. (1999). Orphanet: an online rare disease and orphan drug data base. Adducted thumbs-arthrogryposis syndrome, Christian type. ORPHA:2952

Adducted thumbs-arthrogryposis, Christian type is a type of arthrogryposis characterized by congenital cleft palate, microcephaly, craniostenosis and arthrog ryposis (limitation of extension of elbows, flexed adducted thumbs, camptodactyly and clubfeet). Additional features include facial dysmorphism ("myopathic" stiff face, antimongoloid slanting, external ophthalmoplegia, telecanthus, low-set large malrotated ears, open mouth, mierogenia and high arched palate). Velopharyngeal insufficiency with difficulties in swallowing, increased secretion of the nose and throat, prominent occiput, generalized muscular hypotonia with mild cyanosis and no spontaneous movements, seizures, torticollis, areflexia, intellectual disability, hypertrichosis of the lower extremities, and scleredema (in the first days of life; see this term) are also observed. The disease often leads to early death. Transmission is autosomal recessive. No new cases of adducted thumbs-arthrogryposis, Christian type have been described since 1983. 